\title{
Tribalization of politics in authoritarian regimes: Analysis of the link between political tribalism and right-wing authoritarianism in Cameroon
}

\author{
Gustave Adolphe MESSANGA \& Sonia NPIANE NGONGUEU \\ Department of Philosophy-Psychology-Sociology, University of Dschang, Cameroon
}

\begin{abstract}
This study analyzes the Relationship between political tribalism and right-Wing authoritarianism in Cameroon. It assumes That there is a positive and significant link between those two constructs. 191 Beti students, including 111 women and 80 men attending the universities of Dschang and Yaounde 1 were selected as participants. Their average age is 26.96 years. The choice made on Beti tribe is linked to the fact that literature reveals that political tribalism is mostly observed among dominant ethnic groups (Lonsdale, 2011). Data collection was done using a political tribalism's scale constructed for the purposes of the study and Dunwoody and Funke's (2016) rightwing authoritarianism scale, revised and adapted to cameroonian context by Npiane Ngongueu (2018). Analyzes provide empirical support for the hypothesis of the study $(r=.15, p<.05)$. Thus, this study contributes to the advancement of theoretical knowledge about authoritarian personality. In agreement with literature, it can be said that authoritarianism makes it possible to understand psychological basis of many sociopolitical and intergroup behaviors, such as tribalism (Shaffer \& Duckitt, 2013).
\end{abstract}

Keywords : Political Tribalism, right-Wing authoritarianism, inter group discrimination, in group favoritismes, out group derogation.

\section{INTRODUCTION}

I nvestigations on discriminatory ideologies were introduced into social science field by authoritarian personality theory (Adorno et al., 1950). In their wake, studies have been conducted in the fields of psychology and political science, about the mechanisms of membership in fascist, totalitarian, conservatist and racist movements. This theory allows to understand discriminatory attitudes (tribalism, ethnocentrism, racism, anti-Semitism), right-wing authoritarianism, unconditional submission to authority, tolerance of aggression, repression against deviant groups or minorities, conventionalism, conformism, and support for repressive and liberticidal policies.

In ethnically diverse sub-Saharan African countries, discriminatory and unequal policies are often tribal in nature. This situation is caused by the sometimes exceptional complexity of the ethnic configuration of their populations. For example, recent classifications list about two hundred identifiable ethnic groups in Cameroon (Zognong, 2002). The mode of governance of this country takes this ethnic diversity into account (Onana Onomo, 2002). This is why, in social sciences vocabulary, Cameroon is considered as an ethnocracy, that is to say a country based on a system of government which draws its resources and specifies its ins and outs essentially in the competition between ethnic groups. In practice, literature reveals that political elites tend to apply public policies by allocating more resources and power to members of their tribe, to the detriment of citizens belonging to other tribes (Berman et al., 2004). This behavioral tendency, known as political tribalism, is defined as the use of tribal membership in political competition between groups (Lonsdale, 2011). It is an instrument for the conquest and preservation of political and/or economic power, used by members of dominant groups. Eifert et al. (2010) argue that this preferential treatment for a tribe prompts its members to defend status quo, ideologies which are favorable to authorities, conventions, rejection of deviants, discrimination and aggression towards outgroups. It is at this level that one can make a connection between political tribalism and authoritarian predispositions, since right-wing authoritarianism is translated into positive attitudes towards ingroup and discriminatory, hostile and negative attitudes towards outgroups (Bourhis \& Leyens, 1999). In this perspective, it should be noted that although at first glance, the links between these two constructs seem logical, they are yet to be established in the specialized literature. But, authoritarianism would make it possible to understand the psychological foundations of many sociopolitical and intergroup behaviors, such as discriminatory behavior, of which tribalism is one of the variants (Shaffer \& Duckitt, 2013).

\section{Right-wing authoritarianism}

The concept of authoritarianism has several meanings. It reflects the character of people marked by submission to authority, considered as all-powerful, and offering a lifeline in a dangerous and difficult to predict's world (Adorno et al., 1950; Altemeyer, 1981). Authoritarianism is a personal disposition that values group level conformity to the detriment of individual autonomy, and which at the same time leads to the formation of ideological positions, and to partisan polarization in the political field (Hetherington \& Suhay 2011; Hetherington \& Weiler, 2009). 
Social psychology of intergroup relations teaches that individuals tend to identify with their group of belonging. As a result, they are forced to conform to that group's norms if they wish to be accepted by other members and avoid social isolation. Thus, authoritarianism is a behavior strongly determined by individuals' categorial affiliation. This is why their affiliation with political groups, for example, is less the result of a subjective ideology than of a type of social order and structure provided by the identity of the group to which they belong. In this logic, Hetherington and Weiler (2009) argue that authoritarianism is an individual's predisposition to order, security and certainty that structures a worldview of ideas. It leads to the reduction of uncertainty in dangerous situations or social instability. The literature reveals, in this regard, that the latent dispositions generally correlated with the construction of authoritarianism consist of greater needs for order, structure and closure; intolerance of confusion, ambiguity and uncertainty; and the increased use of established powers to maintain order (Jost et al., 2003; Kruglanski \& Webster, 1996).

Authoritarianism is the first ideological construct to be theoretically and empirically linked to a personal sense of threat (Adorno et al., 1950). Indeed, Fromm (1941) proposes that individuals ignore their freedom and lean towards authoritarianism when faced with a threatening and uncertain world. In fact, people who complain about the authoritarianism of the system tend to be more sensitive to threatening words and messages (Lavine et al., 2002). The literature also reveals the link between fear and authoritarianism, showing that in the general population, authoritarianism increases during times of high societal threats, especially those when individuals face unemployment, crime and war (Doty et al., 1991). Several studies carried out in the aftermath of the September 11 attacks indicate that those most threatened or most concerned by their security following terrorist acts are the least favorable to civil liberties (Cohrs et al., 2005). Likewise, Duckitt and Fisher (2003) find that presenting individuals with a threatening scenario (in which the crime rate, economy and general prosperity of their country were described as worsening in the future) increases their affinity for authoritarianism. Studies of individual differences show a strong correlation between the tendency to perceive the world as dangerous and right-wing authoritarianism, measured with Altemeyer's (1998) Right Wing Authoritarianism scale (RWA). Thus, an empirical link exists between measured or manipulated threat and authoritarianism. Concretely, difficult social conditions, periods of social instability, protest and repression, as well as the perception of a threat can increase the authoritarianism's feeling.

Some authors conceptualize authoritarianism as a set of personality-oriented social values (Duckitt \& Fisher, 2003; Sibley \& Duckitt, 2008) and defined it as a predisposition to be subjected to a legitimate authoritative entity, which maintains social order (Altemeyer, 1988; Feldman, 2003).
Based on previous work that describes authoritarianism as emanating from group membership (Duckitt, 1989; Duckitt \& Fisher, 2003), it is important to specify that attachment to social groups is an integral part of social systems, authoritarian beliefs, attitudes and behavioral tendencies. In addition, according to Duckitt (2001), authoritarianism is linked to the belief in a dangerous world based on two dimensions, including the desire to maintain coercive social control and conservatism, i.e. willingness to maintain the existing status quo and moral values. These dimensions are similar to Altemeyer's (1988) three groups of attitudes, including authoritarian submission, authoritarian aggression, and conventionalism, which have been reconstructed as a continuum between individual autonomy and group conformity (Feldman, 2003). This conceptualization, along the autonomy-conformity continuum, views individuals' orientations towards society as interactions between latent dispositions and perceived social threat (Feldman, 2003; Feldman \& Stenner, 1997). From this point of view, environmental factors have an influence on the tendency to adopt authoritarian behavior (Altemeyer, 1988).

The concept of right-wing authoritarianism is underpinned by a political ideology marked by social inequalities. We conceive, in fact, right-wing ideology as a set of ideas based on the legitimization of social inequalities, dominance relations, and social status quo (Jost et al., 2009). It is based on conformism, the weight of tradition, submission, and aggression against deviants or ethnic minorities. This ideology is based on the fact that a threat or danger hangs over the world, jeopardizing its sustainability. It is then perceived as a dangerous space where one must obey order, in order not to be excluded from society (Feldman, 2003). This ideology is at the root of right-wing authoritarianism.

Right-wing authoritarianism is characterized by an ideology based on exclusion and social inequalities. It is a personality orientation and an ideological variable studied in political science and social psychology. It is expressed in radical forms such as racism, ethnocentrism, conservatism, nationalism and anti-Semitism. It is generally linked to acceptance of violence and tolerance for aggression (Altemeyer, 2001). Indeed, rightwing authoritarians are people with a high degree of willingness to submit to authorities perceived as legitimate. They adhere to societal conventions, norms, and adopt hostile or punitive attitudes towards those who do not. They value uniformity and conformity of groups by using repression as a means to achieve it.

\section{Authoritarianism and intergroup discrimination}

Discrimination has been the subject of heated debates among politicians, social scientists and economists. It takes many forms, including discrimination based on sex, sexual orientation, race or religion. Most of the definitions offered by social psychology of discrimination take the notion of prejudice into account. Indeed, Brown (1995) considers that it is about maintenance of negative attitudes or beliefs, 
expression of negative affects or implementation of hostile or discriminatory behaviors towards members of a group because of their membership in that group. According to Dovidio et al., (2000), discrimination is a negative behavior towards prejudiced outgroup members. It means that prejudice is seen as the root cause of discrimination, conceived as a gradual multi-step process marked by increasingly harmful behaviors for outgroup' members (Allport, 1954). The first corresponds to verbal antagonism (occasional racial insults, comments aimed at denigrating the target in its presence or not...). This stage tends to create a hostile social environment (work, school, neighborhood, etc.) (Stone et al., 1993). If nothing stops it, it leads to the second step: avoidance. It is about the individual prioritizing interactions with ingroup's members, which can lead to isolation of outgroup's members, and later to segregation and exclusion. Sibley and Duckitt (2008) argue that hate crimes are linked to explicit expression of prejudice, and arise in response to a sense of economic or symbolic threat experienced by the perpetrator. The last step goes up to an attempt to exterminate outgroup's members (genocide). It emerges in situations of strong leadership, institutionalized prejudice and discrimination, as was the case in Nazi' Germany. In this perspective, discrimination is sometimes seen as the conative (behavioral) component that arises from prejudice (Wilder, 1978).

In the context of intergroup relations, discrimination has a pejorative meaning. It implies a certain distinction between social groups, a differentiated, inappropriate and potentially unfair treatment between individuals, because of their group membership. According to Allport (1954), it excludes equal treatment. This is why it is conceived as a set of actions whose purpose is to keep the characteristics of ingroup in a privileged position to the detriment of outgroup (Sibley \& Duckitt, 2008). Thus, it refers to biased behavior that includes not only actions that directly harm or disadvantage another group, but also those that unfairly favor one's own group. It therefore aims to create a relative disadvantage for outgroup.

The process of group formation involves a social categorization which activates the processes of social identification and, in turn, promotes the feeling of belonging to a group. As a result, individuals might behave differently towards outgroups' members depending on their social preferences (Duckitt, 2001). Analysis of social identity theory suggests that intergroup discrimination and ingroup favoritism already occurs when individuals are attributed an arbitrary social identity. Indeed, Turner et al. (1979) observe that the arbitrary distribution of individuals into groups generates more intragroup than intergroup altruism. These results have their social relevance in the world through conservative ideologies. Indeed, the social identity theorem partly explains many real events, such as blatant racism, tribalism and nativism, which have occurred in the past, and are observed so far.

Discrimination is a characteristic of authoritarian behavior (Altemeyer, 1998). In fact, right-wing authoritarianism refers to an individual's predisposition to support intolerance, intergroup discrimination, social inequalities, violence against deviant outgroups and total adherence to right's political ideology. From the theoretical perspective of Adorno et al. (1950), authoritarianism is characterized by stereotyping, prejudice and discrimination. It means that supporting authoritarian policies involves ingroup favoritism and hostile attitudes towards outgroup's members. In this sense, on the axis of pro ingroup favoritism, authoritarian attitudes translate into veneration of group' authority, respect for its conventions and norms, defense of group' interests, and rejection of deviant members. On the axis of hostile attitudes towards outgroup's members, it result in prejudices and stereotypes, as well as adoption of hostile and discriminatory behaviors (Fromm, 1941; Peterson et al., 1993; Stone et al., 1993). Authoritarianism is thus linked to prejudices and discriminations towards minority groups, hence the intolerance observed towards deviant groups, which deviate from social values and norms (Feldman, 2003; Van Hiel \& Mervielde, 2005). It can be concluded that authoritarianism, like intergroup discrimination, has very strong correlations with variables that accentuate inequalities, such as ethnic prejudices (Altemeyer, 1981; 1988; 1996).

Ethnic prejudices, with tribalism as a corollary, are closely linked to intergroup discrimination. Tribalism, also called ethnocentrism, can be seen as a form of discrimination because it is adopted by individuals with the aim of strengthening tribal solidarity, defending and justifying their interest and identity against outgroups (Kimenyi, 2006). Myers (1994) defines it as a belief in the superiority of one's own group and a general disdain for other groups. According to Nwaigbo (2005), it implies a strong distinction between ingroup and outgroup. It is an attitude marked by strong attachment, loyalty to one's tribe and demonization of other tribal groups (Nothwehr, 2008). It prompts individual to adopt a positive attitude towards people related to him (directly or indirectly through kinship, family, clan and ethnicity) and reject members of others tribes (Nwaigbo, 2005). It is therefore a doctrine which consists of unreasonable favoritism towards certain individuals, on the basis of community ties; hence the fact that it can be considered as an ethnic instrumentation (Mankou, 2007). While prejudice can be seen as negative evaluation and hostility towards a social group, tribalism includes the tendency to form and maintain negative evaluations and hostility towards groups that have individual or cultural differences with ingroup.

Tribalism is described as an ideological system. From this perspective, the traditional conception of ethnocentrism is considered to differ in several respects from the usual notion of prejudice, generally seen as a feeling of aversion towards a specific group, as is the case for racial (Blacks in the United States) and religious minorities (Coptic Christians in Egypt) (Levinson, 1950). Tribalism, on the other hand, refers to a relatively consistent mindset about outsiders in general. It refers to group relations. It is not just about the many related 
groups towards which individuals have hostile views and attitudes; it is equally important for the groups towards which they are positively disposed. According to Sanders (2007), it helps to define the characteristics of a social group. Indeed, people inclined to support tribalism tend to assess cultural similarity positively, and reject strangeness without questioning it (Adorno et al., 1950). Thus, tribalism includes an overvaluation or idealization of ingroup as much as a devaluation of outgroups. It is the reason why it is seen as a form of intergroup discrimination based on ethnic prejudice. This discrimination is observable in many domains, including economy, social, or politics which is the focus of this research (Kimenyi, 2006; Lonsdale, 1994).

The current research: political tribalism and right-wing authoritarianism in Cameroon

In its political dimension, tribalism is generally seen as a problematic feature of African societies, rather than as a legitimate mode of political representation. According to Lonsdale (2011), there is a contrast between political tribalism (use of ethnic identity in political competition with other groups) and moral ethnicity (common human instinct to create from daily habits and social relationships, a system of moral sense and ethical reputation within a more or less imagined community). This author indicates that political tribalism refers to the use of tribal affiliation by a group in its struggle with other groups. This is why Berman et al. (2004) see it as essentially amoral, as it promotes general success of an ethnic group, by giving its members more power and available resources, despite the consequences of such acts on other groups. Thus, whether at the national or local levels, tribal leaders seek to maximize their group's representation in the state. It is a tribalism built by individuals belonging to a dominant social class, with a view to safeguarding their personal interests. In this logic, it appears as an instrument for the conquest and conservation of political and/or economic power by the group which uses it.

In the political context, tribalization begins with a definition of categorization which allows circumscribing the limits of the tribe. This process is based on collective identities which create illusion of living in a small group sharing the same values, grievances and political desires. It ends with the definition of a foreigner, a discriminated and eventually rejected outgroup by ingroup's members. Although tribalization lies in the formation of political identities, it can be accelerated depending on certain structural conditions. Indeed, when individuals are in a context where their survival is threatened by economic crises, wars, political instability or terrorist attacks, it is very important to remain attached to their tribe. This tribal solidarity provides a sense of security, while respect for tribal cultural values brings back the meaning of life. While according to Balandier, tribe was a modern means of finding refuge in a situation of threat and uncertainty, today it is equated with a modern business, an economic region or a profession, and not with an ethnic cultural heritage (Lonsdale, 2011).
In Cameroon, tribalization of politics is visible in very specific areas. Indeed, ethnic antagonisms manifest themselves directly in the political field, as shown by ethnic polarization of vote during presidential elections. Indeed, specialized literature reveals a strong preference of citizens for their tribe's candidate (Roubaud, 1995; Roubaud et al., 2006). Another observation shows that voters of the same party are concentrated in the same geographical area. Indeed, the survey carried out in 1993 by CRETES gives a relatively reliable picture of the political sensitivity of Cameroonians, depending on their region of origin (Roubaud, 1995). This organization notes that nationally, people from the Center, East and South regions, predominantly Beti, are much more favorable to the ruling party (CPDM) than their compatriots. Thus, $46 \%$ of natives of these three regions consider this party to be closest to their convictions, while barely $5 \%$ of natives of the West, South-West and North-West regions are in this case.

In ethnically diverse sub-Saharan African countries, political leaders increase their chances of remaining in power by sharing the resulting benefits, and by regularly replacing their ministers (François et al., $2014 \mathrm{a}$ and b). These leaders invest disproportionately in their home communities. These maneuvers are particularly useful because it give them the political support they need to stay in power. Thus, they are more likely to mobilize popular support by creating political parties and using them to procure benefits from masses (Geddes, 2005). Indeed, literature reveals that in sub-Saharan Africa, where politics tends to be strongly centralized around executive power (Posner, 2007; Van de Walle, 2003), the ethnic group of the country's leader is generally the most favored, and politically dominant (Posner, 2005). Politicians try to mobilize ethnic groups to compete for central political power; emphasizing inter-ethnic divides (Posner, 2004). They play ethnic card at the edge of electoral competitions, and members of their ethnic constituencies vote them in hopes of future allocation of resources for the development of their localities (Eifert et al., 2010). In this perspective, one can clearly see the relevance of relations between ethnic and political diversity theorized by Bates (2000) and Collier (2001). Indeed, these authors show that competition for political representation and jobs tends to increase the likelihood that a person identifies with its ethnicity, and this attitude impacts on intergroup relations.

Hintjens (2001) argues that political tribalism can lead to violence in social relations. These tribal conflicts and violence are fueled by ethnic prejudices linked to tribal loyalties relating to politics. Indeed, stereotypical perception of outgroups, respect for authorities, values and norms are characteristics of tribalist people (Scheepers et al., 1990). Outgroups' stereotypes imply not only negative images and hostile attitudes, but also a rigid distinction between groups (Levinson, 1950). Political tribalism involves politicization of tribal identities which can lead to polarization and rivalry between tribes. Polarization of society and the resulting ethnic divide could generate relations of domination and tribal 
hierarchies leading to social inequalities (Lonsdale, 2011). These can lead to different forms of conflict, including the most extreme, linked to political factors; hence the positive correlation between political tribalism and violent tendencies, including propensity for political violence, aggressiveness in daily life, and endorsement of sexual and gender-based violence (Posner, 2007).

In a context marked by political tribalism, unequal distribution of resources by politicians, with a notable inclination for preferential treatment favoring their tribe, could encourage its members to defend ingroup ideologies, be submitted to authorities, respect group conventions, reject their deviant members, and tolerate discrimination and aggression towards outgroups. These manifestations of political tribalism seem to correspond to authoritarian predispositions. Indeed, Altemeyer's work (2012), focusing on right-wing authoritarianism, suggests that it is strongly linked, among others, to aggressiveness, violence in general, prejudices and stereotypes, submission, conventionalism, political conservatism, social dominance, and intergroup discrimination. Moreover, according to Shaffer and Duckitt (2013), authoritarianism helps to understand the psychological basis of many sociopolitical and intergroup behaviors. Political tribalism is a sociopolitical behavior that affects intergroup relations in general and intergroup discrimination in particular. This thesis is supported by numerous studies which reveal that authoritarianism is a powerful predictor of prejudice and discrimination (Altemeyer, 1998; Van Hiel \& Mervielde, 2002, 2005; Whitley, 1999). Thus, if there are theoretical links between authoritarianism and discrimination (Shaffer \& Duckitt, 2013), and if the characteristics of political tribalism, which involve discriminatory behavior, are looking like those of authoritarianism, then one can suggest that these two concepts could be theoretically correlated. The scientific project of this study is to see if this hypothetical theoretical relationship is real, by answering the following research question: is the link between political tribalism and right-wing authoritarianism significant?

\section{HYPOTHESIS}

This study tests the hypothesis that there is a positive and significant link between political tribalism and right-wing authoritarianism in Cameroon. In other words, at the end of the empirical investigation, it is expected that the participants who will be inclined to adopt discriminatory attitudes and behaviors (favorable to ingroup and unfavorable towards outgroup) based on their ethnic's affiliation (political tribalism) will also tend to legitimize social inequalities, dominance relations and social status quo (right-wing authoritarianism).

\section{METHOD}

\section{Participants}

191 students belonging to the Beti ethnic group, including 111 women and 80 men, attending the Universities of Dschang and Yaounde 1 participated in this study. They are between 17 and 48 years old $(M=26.96 ; S D=9.82)$. Beti are part of the large Pahouin group which occupies the region between middle Sanaga and the mouth of Ogooué in latitude and longitude between Atlantic Ocean and middle Sangha. In Cameroon, their area of residence is covering the administrative regions of Center and South; the latter being the region of origin of the Head of State, Paul Biya. This group is made up, among others, of Ewondo, Manguissa, Mvélé, Mbida-Mbani, Bëne, Eton, Ntoumou, and Tsinga (Abega, 1984). The choice made for this group is linked to the fact that literature reveals that political tribalism is the preserve of dominant ethnic groups (Lonsdale, 2011). Indeed, as Onana Onomo (2002) points out, in the cameroonian national scene, one can consider that Beti have the mastery of the socio-administrative apparatus.

\section{Material and procedure}

In this study, data are collected using two scales, one that assesses political tribalism and the other that examines the tendency for right-wing authoritarianism among participants. The first was developed for the purposes of this research, drawing on the literature on the concept of political tribalism in general and its indicators in particular (Berman et al., 2004; Hintjens, 2001; Lonsdale, 2011; Posner, 2007). To generate the items of this instrument, two aspects of the literature were retained. These are: 1) pro-ingroup attitudes/behaviors. For instance, item 1 reads as follows: The elites of my tribe should have prestigious positions in the administration of this country; and 2) anti-outgroup attitudes/behaviors. For example, item 11 is worded as follows: It would bother me if the political elites of my tribe innovate in the development of other tribes. This two-dimensional instrument has 16 items, including 8 per dimension. They are all coded in the rightside. The internal consistency index of this scale is within the standards required for a psychometric instrument $(\alpha=.831)$. The maximum score for this scale is 112 points, and the minimum score 16 points. The participants' task is to give their opinion on each of the statements of the scale, circling the number that reflects the degree to which they agree with it. This adherence is assessed on a 7-points Likert-type scale, ranging from 1 (strongly disagree) to 7 (strongly agree).

The assessment of the tendency to extreme right-wing authoritarianism was made using the Dunwoody and Funke's scale (2016), revised and adapted to the Cameroonian context by Npiane Ngongueu (2018). This preference is justified by the fact that this version of the scale was validated in an undemocratic political context. It includes 18 items divided into 3 groups of 6 items each, according to the dimension of authoritarianism measured (submission, conventionalism, and aggressiveness). Its internal consistency index is within the standards required for a psychometric instrument $(\alpha=.74)$. This scale includes as many right-side coded items (9) as reverse coded items (9). For example, item 3 suggests that: It is necessary to criticize statements made by those in positions of authority. Item 10, on the other hand, states that: To respect 
social traditions is to move away from progress. The maximum score for this scale is 126 points, and the minimum score is 18 points. The task of the participants is the same as for the political tribalism's scale.

\section{IV.RESULTS}

The results of this research are presented in two steps. First, we are interested in descriptive and correlational analyzes between the two variables evaluated. Second, a linear regression analysis is used to analyze the possible causal relationship between these two constructs.

Table 1: Presentation matrix for means (M), standard deviations (SD) and linear correlation indices (r)

\begin{tabular}{|c|c|c|c|c|c|c|c|c|c|}
\hline & M & S-D. & 1 & 2 & 3 & 4 & 5 & 6 & 7 \\
\hline $\begin{array}{c}\text { 1.Pro-ingroup } \\
\text { attitude/behaviour }\end{array}$ & 30.47 & 11.42 & 1 & & & & & & \\
\hline $\begin{array}{l}\text { 2.Anti-outgroup } \\
\text { attitude/bahaviour }\end{array}$ & 28.33 & 10.57 & $.414^{* *}$ & 1 & & & & & \\
\hline 3.Submission & 23.84 & 5.54 & .132 & $.204^{* *}$ & 1 & & & & \\
\hline 4.Conventionnalism & 29.65 & 4.93 & . 088 & .074 & $.351^{* *}$ & 1 & & & \\
\hline 5.Aggressiveness & 24.99 & 5.3 & -.050 & .082 & -.019 & .132 & 1 & & \\
\hline 6.Tribalism & 58.8 & 18.5 & $.854^{* *}$ & $.827^{* *}$ & $.198^{* *}$ & .097 & .016 & $1(.831)$ & \\
\hline $\begin{array}{c}\text { 7.Right-wing } \\
\text { authoritarianism }\end{array}$ & 78.48 & 10.40 & .087 & $.185^{*}$ & $.690^{* *}$ & $.728^{* *}$ & $.563^{* *}$ & $.159^{*}$ & 1 \\
\hline
\end{tabular}

Note: **. The correlation is significant at the 0.01 level (two-tailed). *. The correlation is significant at the 0.05 level (two-tailed). The item in parentheses represents the Cronbach's Alpha Index of the Political Tribalism Scale.

The data presented in Table 1 reveal that, overall, the participants have an inclination for political tribalism $(\mathrm{M}=$ 58.8> 56; $\mathrm{SD}=18.5$ ). In the details, we observe the same trends for the different dimensions of this scale (with respectively for the dimensions pro-ingroup attitudes/behaviors and anti-outgroup attitudes/behaviors, scores of 30.47 and 28.33, all above the average which is 28 ). This trend is also observed for right-wing authoritarianism (M $=78.48>56 ; \mathrm{SD}=10.40$ ) and its dimensions (with respectively for the dimensions: submission, conventionalism and aggressiveness, scores of 23.84; 29.65; and 24.99; all above the average of 21). These different values predict the existence of a correlation between the two constructs.

There is a positive and significant correlation between political tribalism and right-wing authoritarianism $(\mathrm{r}=.15$; $\mathrm{p}$ $<.05$ ). An in-depth analysis of the data collected indicates that the two dimensions of political tribalism also correlate positively with right-wing authoritarianism (we have a nonsignificant link $\mathrm{r}=.08$ between the dimension of pro-ingroup attitudes/behaviors and right-wing authoritarianism, and a significant link $\mathrm{r}=.185 ; \mathrm{p}<.05$ between anti-outgroup attitudes/behaviors and right-wing authoritarianism). Between the dimensions of right-wing authoritarianism and political tribalism, we observe positive correlations, one of which is significant (we have indices $\mathrm{r}=.19$ with $\mathrm{p}<.01$, between the dimension of submission and political tribalism; $r=.09$ with $p>.05$, between the dimension of conventionalism and political tribalism; and $\mathrm{r}=.016$ with $\mathrm{p}>.05$, between the dimension of aggressiveness and political tribalism). These positive correlations observed on one hand between the dimensions of political tribalism and right-wing authoritarianism and on the other hand between the dimensions of right-wing authoritarianism and political tribalism, confirm the links that exist between these two constructs. Therefore, they confirm the positive and significant correlation between political tribalism and rightwing authoritarianism as revealed by the regression analysis done below.

Table 2: Presentation matrix of the coefficients of the linear equations predicting the effect of political tribalism on right-wing authoritarianism

\begin{tabular}{|c|c|c|c|c|c|c|c|c|c|c|c|}
\hline & \multirow{2}{*}{ Model } & \multicolumn{2}{|c|}{$\begin{array}{l}\text { Non standardized } \\
\text { coefficients }\end{array}$} & \multirow{2}{*}{$\begin{array}{c}\begin{array}{c}\text { Standardized } \\
\text { coefficients }\end{array} \\
\text { Bêta }\end{array}$} & \multirow{2}{*}{$\mathrm{t}$} & \multirow{2}{*}{ Sig. } & \multicolumn{2}{|l|}{ Correlations } & \multicolumn{3}{|c|}{ Collinearity statistics } \\
\hline & & B & standard error & & & & Simple correlation & Partial & Partial & Tolerance & VIF \\
\hline 1 & (Constant) & 73.668 & 2.296 & & 32.088 & .000 & & & & & \\
\hline & Tribal global & .090 & .040 & .159 & 2.219 & .028 & .159 & .159 & .159 & 1 & 1 \\
\hline
\end{tabular}

This matrix has a standardized beta coefficient and a positive $\beta$ t value. Concretely, it means that political tribalism acts positively and significantly on right-wing authoritarianism $(\beta$ $=.159 ; \mathrm{t}=2.21 ; \mathrm{p}<.05)$. These results support the correlational analyzes presented previously, and provide support for the hypothesis of this research. It means that the more people are in favor of political tribalism, the more they support right-wing authoritarianism. In other words, participants who emphasize tribal affiliation in the political competition between groups also tend to support the authorities, their policies and ideologies, as illustrated in Figure 1. 


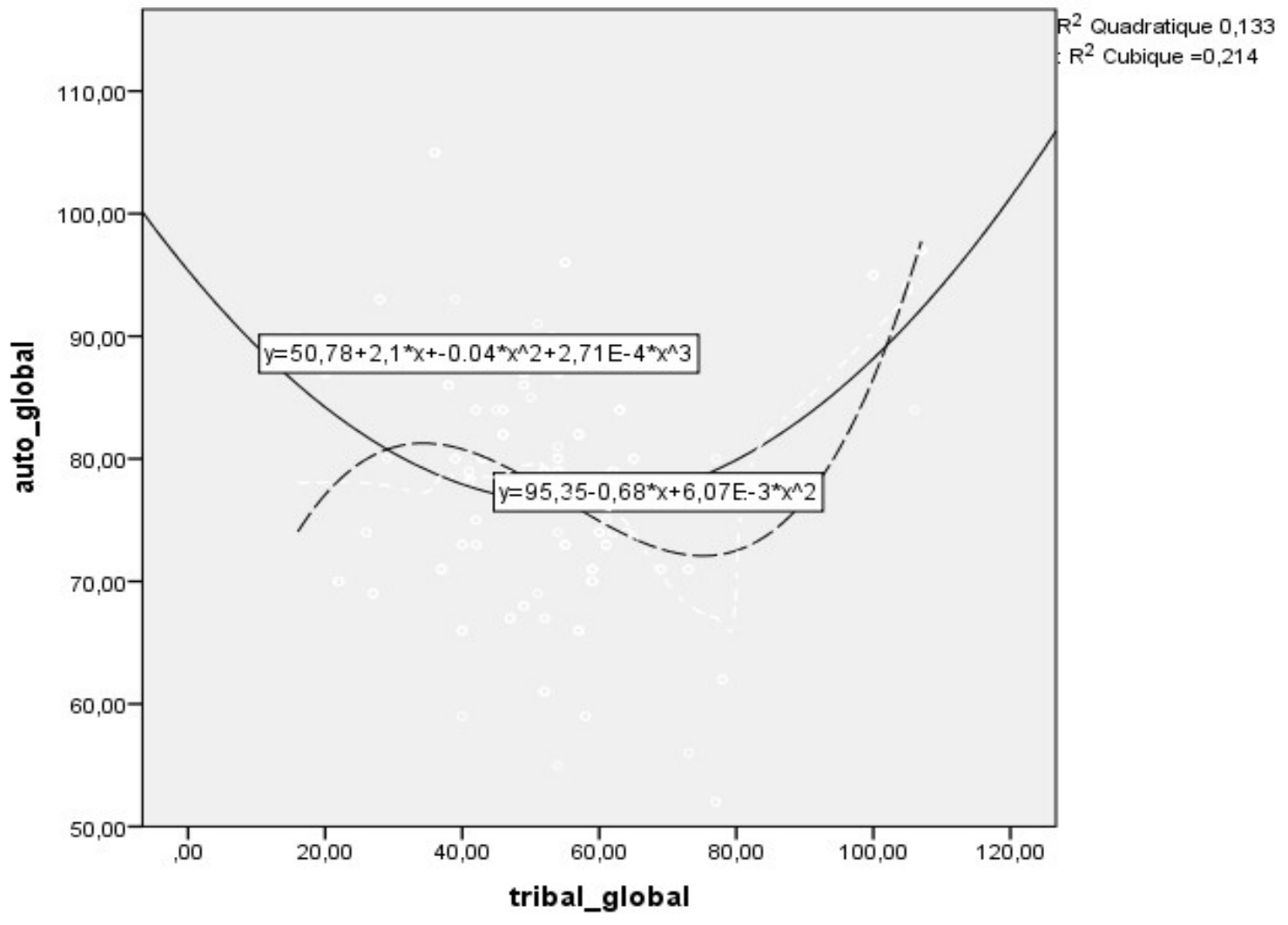

Figure 1: Linear interpolation curve for estimating the value taken by the continuous function between the variables of the study.

This figure shows the variation curves of the factors linked in this study. It shows the trajectory of right-wing authoritarianism following variations in political tribalism or the reciprocal interactions between these two variables. Indeed, when there is variation in political tribalism, we realize that right-wing authoritarianism which begins at a point $\mathrm{x} \_1$ with coordinates 0 and $100\left(\mathrm{x} \_1(0 ; 100)\right)$ decreases by 20 points and arrives at a coordinate point substantially close to $\mathrm{x} \_2(60 ; 80)$. When the index of political tribalism is low, we see that the curve of right-wing authoritarianism tends to decrease. However, this curve increases as this index increases (from 60). We can then say that the more political tribalism grows, the more right-wing authoritarianism grows. It is concluded that the more individuals are in favor of political tribalism, the more they support right-wing authoritarianism.

\section{DISCUSSION}

The objective of this research was to test the hypothesis that there is a positive and significant link between political tribalism and extreme right-wing authoritarianism in Cameroon. Individuals inclined to political tribalism were expected to be favorable to right-wing authoritarianism. The data collected provide empirical support for this hypothesis. They follow the same logic as the literature which reveals that authoritarianism is one of the determinants of intergroup discrimination, of which tribalism is one of the variants (Adorno et al., 1950; Herrmann \& Schmidt, 1995). Tribalists generally have high levels of identification, attachment, and loyalty to their group. Members who question the leaders/authorities of the group or their beliefs are considered deviants. In this sense, the authoritarian personality theory (Adorno et al., 1950) allows us to postulate that authoritarianism predicts tribalism. Indeed, Heaven (1985) suggests that authoritarianism is partly a motivation for success and conventionalism, and partly an inclination to ethnocentrism. This is why Shaffer and Duckitt (2013) argue that it is the psychological basis for many sociopolitical and intergroup behaviors, including tribalism. In the political framework, in fact, tribalism implies the politicization of tribal identities and the polarization of society. The resulting ethnic divide could generate relations of domination and tribal hierarchies likely to lead to social inequalities (Lonsdale, 2011).

The literature reveals that in the predominantly authoritarian sub-Saharan Africa's countries, the ethnicity of the political leader comes into play in social policy. The latter is prone to pro-ingroup ethnic favoritism in the distribution of resources, with the aim of having the support of his owns during elections (Lindberg \& Morrison, 2008). In turn, the members of his group adopt ingroup favorable behaviors, in order to maintain the status quo, favorable to groups at the top of the social hierarchy. It is in this logic that they support authoritarian policies that preserve ingroup's gains, status quo, ideologies of the authorities, conventions, rejection of 
deviants, discrimination and aggression towards outgroup. These characteristics which are specific to political tribalism correspond to authoritarian predispositions.

Borrowing from the literature on distributive politics, we have two main models describing the relationship between the political leader and the members of his ethnic group (Cox \& McCubbins, 1986; Dixit \& Londregan, 1996). These models are often used by political leaders to keep citizens in a position where they are inclined to submit to internal authority, discriminate and reject outgroups. The first model assumes that the political leader guarantees the well-being of his ethnic group. He is still referred to as a model of ethnic altruism because the ruler is assumed to have altruistic preferences towards his ethnic group. The implication of this model is obvious, as members of a particular ethnic group would like their political leaders to do them favors in return for their support. The second model assumes that the political leader is purely an office worker who needs political support ${ }^{1}$. Thus, members of his ethnic group will only support him in exchange for material benefits such as building infrastructure in their locality (schools, hospitals, roads, etc.). In this model, the leader can favor his ethnic group for at least two reasons. First, it may be cheaper for him to buy support from members of his ethnic group because he understands their needs better and can transfer the benefits to them more effectively (Dixit \& Londregan, 1996). Second, it may be less risky for him to trust the promises of his own group that will support him politically in return for the benefits it provide (Cox \& McCubbins, 1986). This model, also called the quid pro quo model, theorizes a mutual exchange of support between the ethnic leader and the ordinary members of his group. These models of political tribalism have several practical implications for African leaders who need broad political support to stay in power. Indeed, the literature reveals that the quid pro quo model is applicable to African autocrats whose political survival depends on the loyalty of a small circle of close allies (Wintrobe, 1998).

Political tribalism is characterized, like authoritarianism, by positive evaluation or idealization of ingroup, discrimination and devaluation of outgroups considered as inferior. Levinson (1950) argues that this discrimination involves stereotypical negative images and hostile attitudes towards outgroups, as well as a hierarchical and authoritarian view of groups' interactions in which some are dominant and others dominated. According to the designers of authoritarian personality theory, prejudice, discrimination and predisposition to accept right-wing ideology and fascist governments are deeply rooted in the psychology of the

\footnotetext{
${ }^{1}$ Former Cameroonian Prime Minister Simon Achidi Achu, with the formula politics na ndjangui, equated politics with tontine. It means that only those who are useful to power can receive power, either by bringing the votes to the party that exercises it, or by providing this party with the material and financial means it needs to carry out its activities and program (Mbassi Bedjoko, 2004).
}

individual (Adorno et al., 1950). As a result of their work, Scheepers et al. (1992) emphasize that people prone to intergroup discrimination respect ingroup, its norms and values, and reject outgroups in general. In the logic of political tribalism, this rejection is evidenced by the stereotypical perception of the tribal characteristics of outgroups (the latter are perceived as aggressive, lazy, untrustworthy, deviant, and not entitled to resources).

\section{CONCLUSION}

The purpose of this study was to see if there is a relationship between political tribalism and right-wing authoritarianism in Cameroon. In the literature, this plausible link has not been established to date, while works indicate that authoritarianism helps to understand the psychological basis of many sociopolitical and intergroup behaviors, including tribalism (Shaffer \& Duckitt, 2013). The results obtained from data collection confirm the hypothesis that there is a positive and significant link between political tribalism and extreme rightwing authoritarianism. At the end of this study, it can be noted that right-wing authoritarianism, just like political tribalism, results in positive attitudes towards ingroup and hostile and negative attitudes towards outgroups. From this perspective, political tribalism, in connection with authoritarianism, can explain the support of individuals for unequal intergroup relations, such as fascist movements, anti-Semitism or racism, which generate authoritarian and anti-democratic political systems (Stellmacher \& Petzel, 2005).

\section{REFERENCES}

[1] Abega, S. C. (1984). L'esana des Beti du sud Cameroun. Thèse de Doctorat de $3^{\text {e }}$ cycle en Anthropologie, Université de Yaoundé.

[2] Adorno, T. W., Frenkel-Brunswik, E., Levinson, D. J., \& Sanford, R. N. (1950). The authoritarian personality. Harper \& Brothers.

[3] Allport, G. (1954). The Nature of Prejudice. Addison-Wesley.

[4] Altemeyer, B. (1981). Right-Wing Authoritarianism. University of Manitoba Press.

[5] Altemeyer, B. (1988). Enemies of freedom : Understanding right-wing authoritarianism. Jossey-Bass Publishers.

[6] Altemeyer, B. (1998). The Other Authoritarian Personality : Advances in Experimental Social Psychology. Academic Press.

[7] Altemeyer, B. (2001). Changing attitudes towards Homosexuals. Journal of Homosexuality, 42, 2, 63-75.

[8] Altemeyer, B. (2004). The other authoritarian personality. In M. P. Zanna (Ed.), Advances in Experimental Social Psychology. Academic Press.

[9] Altemeyer, B. (2006). The authoritarians. Lulu.

[10] Barker, D. C. \& Tinnick, J. D. (2006). Compting vision of parental role and Ideological contraints. American political science review, 100, 249-64.

[11] Bates, R. H. (2000). Ethnicity and Development in Africa : A Reappraisal. AEA Papers and Proceedings, 90, 131-34

[12] Berman, B., Eyoh, D. \& Kymlicka, W. (2004). Ethnicity and Democracy in Africa. James Currey.

[13] Bourhis, R. Y. \& Leyens, J. P. (1999). Stéréotypes, discrimination et relations intergroupes. Mardaga.

[14] Brewer, M. B. (1999). The Psychology of prejudice : In-group love or out-group hate? Journal of Social Issues, 55, 429-444.

[15] Brown, R. (1995). Prejudice: Its social psychology. Blackwell.

[16] Cohrs, J. C., Kielmann, S., Maes, J., \& Moschner, B. (2005). Effects of right-wing authoritarianism and threat from 
terrorism on restriction of civil liberties. Analyses of Social Issues and Public Policy, 5, 263-276.

[17] Collier, P. (2001). Implications of Ethnic Diversity. Economic Policy, 16, 129-66.

[18] Cox, G. \& McCubbins, M. (1986). Electoral politics as a retributive game. Journal of politics, 48, 370-389.

[19] Dixit, A. \& Londregan, J. (1996). The determinates of success of special interest in retributive politics. Journal of politics, 58,4 , 1132-1155.

[20] Doty, R., Peterson, B., \& Winter, D. (1991). Threat and authoritarianism in the United States, 1978-1987. Journal of Personality and Social Psychology, 61, 629-640.

[21] Dovidio, J. F., Major, B., \& Crocker, J. (2000). Stigma : Introduction and overview. In T. F. Heatherton, R. E. Kleck, M. R. Hebl, \& J. G. Hull (Eds.), The social psychology of stigma (pp. 1-28). Guilford.

[22] Duckitt J. (2001). A dual process cognitive-motivational theory of ideology and prejudice. Advances in Experimental Social Psychology, 33, 41-113.

[23] Duckitt, J. \& Fisher, K. (2003). The Impact of Social Threat on Worldview and Ideological Attitudes. Political Psychology, 24(1), 199-222.

[24] Duckitt, J. (1989). Authoritarianism and group identification : A new view of an old construct. Political Psychology, 10, 63-84.

[25] Dunwoody, P. T. \& Funke, F. (2016). The AggressionSubmission-Conventionalism Scale: Testing a New Three Factor Measure of... Journal of Social and Political Psychology, 4, 2, 571-600.

[26] Eifert, B., Miguel, E., \& Posner, D. (2010). Political Competition and Ethnic Identification in Africa. American Journal of Political Science, 54(2), 494-510.

[27] Feldman, S. \& Stenner, K. (1997). Perceived threat and authoritarianism. Political Psychology, 18, 741-770.

[28] Feldman, S. (2003). Values, Ideology, and the Structure of Political Attitudes. Oxford University Press.

[29] François, P., Rainer, I., \& Trebbi, F. (2014 a). How is Power Shared in Africa ?. Econometrica, forthcoming.

[30] François, P., Rainer, I., \& Trebbi, F. (2014 b). The Dictator's Inner Circle. NBER Working Paper, 20216.

[31] Fromm, E. H. (1941). Escape from freedom. Henry Holt and Company.

[32] Geddes, B. (2005). Why Parties and Elections in Authoritarian Regimes? University of California.

[33] Herrmann, A. \& Schmidt, P. (1995). Autoritarisme, Anomie et Ethnocentrisme. In G. Lederer, \& P. Schmidt, (Eds.), Autoritarisme et Société. Leske \& Budrich.

[34] Hetherington, M. J. \& Suhay, E. (2011). Authoritarianism, threat, and Americans' support for the war on terror. American Journal of Political Science, 55, 3, 546-560.

[35] Hetherington, M. J. \& Weiler, J. D. (2009). Authoritarianism and polarization in American politics. Cambridge University Press.

[36] Hintjens, H. (2001). When Identity Becomes a Knife : Reflecting on the Genocide in Rwanda. Ethnicities, 1(1), 25-55.

[37] Jost, J. T., Federico, C. M, \& Napier, J. L. (2009). Political ideology: Its structure functions, and elective affinities. Annual review of Psychology, 60, 307-337.

[38] Jost, J. T., Glaser, J., Kruglanski, A., \& Sulloway, F. (2003). Political conservatism as motivated social cognition. Psychological Bulletin, 129, 339-375.

[39] Kimenyi, M. S. (2006). Ethnicity, Governance and the Provision of Public Goods. Journal of African Economies, 15, 1, 62-99.

[40] Kruglanski, A. W. \& Webster, D. M. (1996). Motivated closing of the mind : Seizing and freezing. Psychological Review, 103, 263-283.

[41] Lavine, H., Lodge, M., Polichak, J., \& Taber, C. (2002). Explicating the black box through experimentation : Studies of authoritarianism and threat. Political Analysis, 10, 342-360.
[42] Levinson, R. N. (1950). The study of ethnocentric ideology. In T.W. Adorno; E. Frenkel-Brunswik; D.J. Levinson, \& R.N. Sanford (Eds), The authoritarian personality (pp.102-150). Harper.

[43] Lindberg, S. I. \& Morrison, M. K. C. (2008). Are African voter really ethnic or clientelistic ? Survey evidence from Ghana. Political Science Quarterly, 123(1), 95-122.

[44] Lonsdale, J. (1994). Moral ethnicity and political tribalism. In P. K. J. Hultin, (ed.), Inventions and Boundaries : Historical and Anthropological Approaches to Ethnicity and Nationalism. Papers from the Researcher Training Course Held at Sandbjerg Manor, 23 to 29 May 1993 (pp. 131-150). Roskilde University.

[45] Lonsdale, J. (2011). Ethnicité morale et tribalisme politique. Cambridge.

[46] Mankou, B. A. (2007). Le tribalisme, source de violence politique et ethnique en Afrique. Revue de philosophie et de sciences humaines, 5 .

[47] Mbassi Bedjoko (2004). Le processus électoral au Cameroun (Mémoire de Master). Université Catholique d'Afrique Centrale, disponible à memoireonline.com/ $/ 1 / 1$

[48] Myers, G. W. (1994). Competitive Rights, Competitive Claims : Land Access in Post-War Mozambique. Journal of Southern African Studies, 20 (4), 603-32.

[49] Nothwehr, D. M. (2008). That they may be one : Catholic social teaching on racism, tribalism, and xenophobia. Orbis Books.

[50] Npiane Ngongueu, S. (2018). Évaluation psychométrique de l'autoritarisme d'extrême dans un contexte non démocratique : révision et validation de l'échelle de mesure tridimensionnelle de Dunwoody et Funke (2016) (Mémoire de Master). Université de Dschang.

[51] Nunnally, J. C. (1978). Psychometric Theory. McGraw-Hill Book.

[52] Nwaigbo, F. (2005). Tribalism versus evangelization in subSaharan africa. African Ecclesial Review, 47(3), 131-159.

[53] Onana Onomo, J.-P. (2002). Symétries hégémoniques BétiBamiléké et rivalités politiques au Cameroun. Disponible à : www.ethnonet-africa.org/pubs/p95cir4.htm

[54] Peterson, B. E., Doty, R. M., \& Winter, D. G. (1993). Authoritarianism and attitudes toward contemporary social issues. Personality and Social Psychology Bulletin, 19, 174-184.

[55] Posner, D. N. (2004). Measuring Ethnic Fractionalization in Africa. American Journal of Political Science, 48, 849-63.

[56] Posner, D. N. (2005). Institutions and Ethnic Politics in Africa. Cambridge University Press.

[57] Posner, D. N. (2007). Forthcoming. Institutions and Ethnic Politics in Africa. Cambridge University Press.

[58] Roubaud, F. (1995). La question ethnique sur le marché du travail à Yaoundé : discrimination ou solidarité ? Contribution pour le Séminaire préparatoire au Sommet Mondial pour le Développement Social. Orstom.

[59] Roubaud, F., Wantchekon L., \& Razafindrakoto, M. (2006). Gouvernance et démocratie en Afrique : la population a son mot à dire. Afrique contemporaine, 4, 220, 21-31.

[60] Sanders, P. (2007). Identity, ethnicity and spirituality. Journal of European Baptist Studies, 7(2), 21-27.

[61] Scheepers, P., Felling, A., \& Peters, J. (1992). Anomie, authoritarianism and ethnocentrism : Update of a classic theme andanempirical test. Politics and the Individual, 2, 43-59.

[62] Scheepers, P., Felling, A., \& Peters, J. (1990). Social conditions, authoritarianism and ethnocentrism : a theoretical model of the earlyFrankfurtSchool updatedand tested. European Sociological Review, 6, 15-29.

[63] Shaffer, B. \& Duckitt, J. (2013). The dimensional structure of people fears, threat, and concerns and their relationship with right-wing authoritarianism and social dominance orientation. International Journal of Psychology, 48, 1, 6-16.

[64] Sibley, C. G. \& Duckitt, J. (2008). Personality and prejudice : A meta-analysis and theoretical review. Personality and Social Psychology Review, 12, 3, 248-279. 
[65] Stellmacher, J. \& Petzel, T. (2005). Authoritarianism as a group phenomenon.

Political

Psychology, 26, 2, 245-274.

[66] Stone, W. F., Lederer, G., \& Christie, R. (1993). Strength and weakness. The authoritarian personality today. Springer.

[67] Turner, J. C., Brown, R. J., \& Tajfel, H. (1979). Social comparison and group interest in ingroup favouritism. European Journal of Social Psychology, 9(2), 187-2014.

[68] Van de Walle, N. (2003). Presidentialism and clientelism in Africa's emerging party systems. Journal of Modern African Studies, 41(2), 297-321

[69] Van Hiel, A. \& Mervielde, I. (2002). Explaining conservative beliefs and political preference : a comparison of social dominance orientation and authoritarianism. Journal of Applied Social Psychology, 32, 965-976.
[70] Van Hiel, A. \& Mervielde, I. (2005). Authoritarianism and social dominance orientation : Relationships with various forms of racism. Journal of Applied Social Psychology, 35(11), 23232344.

[71] Whitley, B. E. (1999). Right-wing authoritarianism, social dominance orientation, and prejudice. Journal of Personality and Social Psychology, 77, 126-134.

[72] Wilder, D. A. (1978). Reduction of Intergroup Discrimination Through Individuation of the Out-Group. Journal of Personality and Social Psychology, 1361-1374.

[73] Wintrobe, R. (1998). The political economy of dictatorship. Cambridge University Press.

[74] Zognong, D. (2002). La question Bamiléké pendant l'ouverture démocratique au Cameroun : Retour d'un débat occulté. Disponible à www.unesco.org/most/dpzognong.htm 